\title{
Bioethics and War
}

\author{
MICHAEL GROSS
}

Modern war poses hard ethical problems for the practice of medicine, making it difficult to identify medical ethics during times of armed conflict with medical ethics during times of peace. This sets up an enduring challenge for medicine, as doctors and other healthcare professionals weigh their responsibilities as caregivers against other responsibilities and obligations that citizens must shoulder during war.

This Special Section on Bioethics and War opens with a historical overview of ethics, medicine, and war by David A. Bennahum. Moving rapidly from ancient practices of war through the Middle Ages and emergence of just war theory to the growth of modern humanitarian law, he describes the role of physicians during war and the dilemmas they confront. These reflect the difficulty of providing quality care in the face of novel wounds and grueling battlefield conditions, distributing scarce medical resources fairly, and safeguarding patient rights. Although these activities constitute the brunt of military medicine, things changed by the second half of the 20th century and into the 21st, when medical workers would not only command the wherewithal to deliver superb care to the battlefield but would also face the call to use their medical expertise to wage war. We see this today as medical personnel are asked to participate in weapons development and interrogation.

Prior to the advent of chemical and biological weapons, physicians had very little to contribute to the development of weapons. In Bennahum's article, we meet Niccolò Tartaglia, a 16th century Italian mathematician who, after discovering the principles of ballistics, burned his notes lest science lend a hand to "mass slaughter." Should physicians do likewise or should they join the ranks of those scientists who contribute their expertise to the prosecution of war?

Two essays consider the roles of physicians in the development of chemical and biological weapons. Ulf Schmidt investigates the history of weapons development at the United Kingdom's facility in Porton Down following World War II, a time that saw intense interest in unconventional means of warfare. Research not only required physicians to use medical knowledge to wage war, but also necessitated human experimentation. This created a twofold dilemma for healthcare professionals that spoke to their obligation to preserve the integrity of their profession and their duty to protect the interests of their patients. Whereas Schmidt focuses on a particular incident in a particular facility, Douglas Holdstock takes a broader view of these problems, as he first surveys the history of biological and chemical weapons development and then focuses on the dangers that unknown or genetically engineered viruses or 
pathogens may bring if used to wage war. There is a growing fear that rogue nations or substate actors will ignore the conventions that tightly control biological and chemical weapons and will appropriate scientific knowledge intended for peaceful purposes to wreak havoc with the laws of armed conflict and sow terror.

As many Western nations confront the threat of terror, they may find themselves contemplating harsh interrogational methods, often akin to torture, to elicit the information they need to protect their citizens. Outlawed by the Convention against Torture and other international declarations, no nation may consider torture, whether facing war, the threat of war, or any other public emergency. Nevertheless, a number of democratic nations-Great Britain, Israel, and the United States - have used torture to prevent grievous harm to innocent victims of terror. Is this practice permissible? Should physicians and other medical personnel lend their expertise where needed?

Two essays explore this issue from different perspectives. On one hand, Leslie London, Leonard S. Rubenstein, Laurel Baldwin-Ragaven, and Adriaan Van Es set aside any consideration of utility in deference to an absolute duty to respect human rights of all persons, no matter how heinous their offense. Fritz Allhoff, on the other hand, considers "hostile" interrogation techniques fundamentally different from those termed "torture." As a result, physicians may, and indeed must, offer care to detainees held for questioning. At the same time, he argues, physicians may also have an active role to play as they help investigators formulate effective plans for interrogation. Active interrogation distances medical personnel far from their caregiving roles, an outcome Allhoff accepts, but one that London and his colleagues vigorously condemn.

Interestingly, these authors do not see torture as a dilemma, if by this we mean a situation that forces an agent to choose between two mutually exclusive, moral imperatives. Ordinarily, the dilemma of torture turns on the inability to preserve the dignity of some (terrorists, for example) and, at the same time, protect the lives of others (innocent victims, for example). Faced with "ticking bombs," something has to give. These essays reject any attempt to set up the problem in this way. For London, Rubenstein, Baldwin-Ragaven, and Van Es torture is always wrong; for Allhoff it is a legitimate tactic of war or law enforcement that specially trained investigators may perform. My own understanding lies somewhere in the middle: Torture remains a hard dilemma that cannot be solved by an absolute commitment to human rights (for what of the human rights of the victim?) or by recasting physicians in a role other than doctors (that is, as medically trained interrogators) who serve the interests of state rather than medicine. Even as interrogators with medical degrees, investigators remain a party to torture and must answer for their acts.

The blurring of medical and military roles, and of medicine's healing and wounding functions, draws us into the final article in this section. Discussing the metaphorical depiction of medicine as war, and war as medicine, Ann Mongoven aims to restore the bright-line distinction between the two. This project is particularly important as contemporary war redefines itself in the wake of international terror. Fighting terror, as noted in the articles by London, Rubenstein, Baldwin-Ragaven, and Van Es and Allhoff, raises the specter of civil and human rights abuses that may not only include torture but long-term detention or deportation with little recourse to legal proceedings. Mongoven wonders whether this is linked to our perception of terror as malignant disease 


\section{Guest Editorial}

and the need to wage a no-holds-barred total war of eradication in response. However one answers this question it cannot but affect the rights of prisoners of war and patients alike.

The second part of this special section presents two new position papers of the American Medical Association's Council on Ethical and Judicial Affairs that are particularly germane in the context of bioethics and armed conflict. The first, "Physician Obligation in Disaster Preparedness and Response," is especially important in light of the on-going debate over the U.S. government's rescue efforts following Hurricane Katrina. Katrina was not an armed attack by a foreign power, but a disaster that strained American defenses nonetheless. In these situations, the AMA looks to strike a careful balance between a physician's autonomy of action, professional obligations, and civic responsibility, never an easy task during war or public emergency. To respond to the AMA's position, we invited commentaries by G. Caleb Alexander, Natalie J. Grove, John D. Lantos, Paul M. McNeill, Rosamond Rhodes, and Anthony B. Zwi.

The second position paper formulates "Guidelines to Prevent Malevolent Use of Biomedical Research," an issue Douglas Holdstock also raises in his paper, as he considers the ethical implications of biological weapons development. The capability of some technologies to serve beneficent as well as malevolent ends is not a new problem, having plagued nuclear technology since its inception, but it is a relatively new one for medicine, as the promise of genetic engineering also holds the potential of mass destruction. Restricting research, or access to research, in these fields threatens to impede the free flow of information so essential to the welfare of democratic societies, medical practice, and scientific development. Michael E. Frisina, Benjamin J. Krohmal, Michael J. Selgelid, and Gregory K. Sobolski evaluate the cogency and effectiveness of the AMA guidelines.

The essays, position papers, and commentaries comprising this special section on bioethics and armed conflict have already sparked a lively discussion among the contributors and commentators. More will follow as the public takes an active interest in the increasingly complex issues presented by medicine and modern war. 


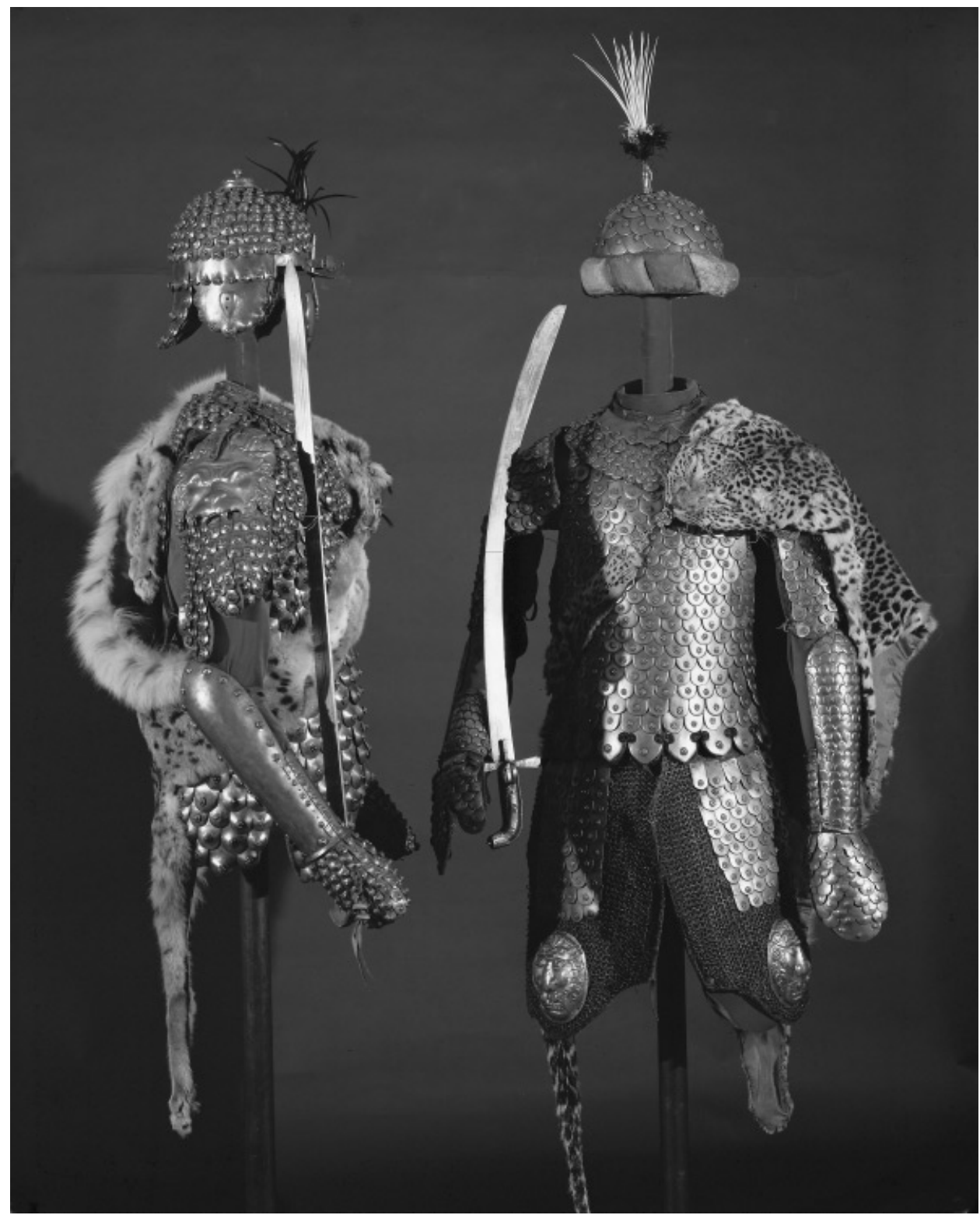

17th century CE. Two sets of Polish scale-armor (Karacena) with leopard skins, helmets and sabers. Wawel Castle, Cracow, Poland. Photo Credit: Erich Lessing/Art Resources, New York. Reproduced by permission. 